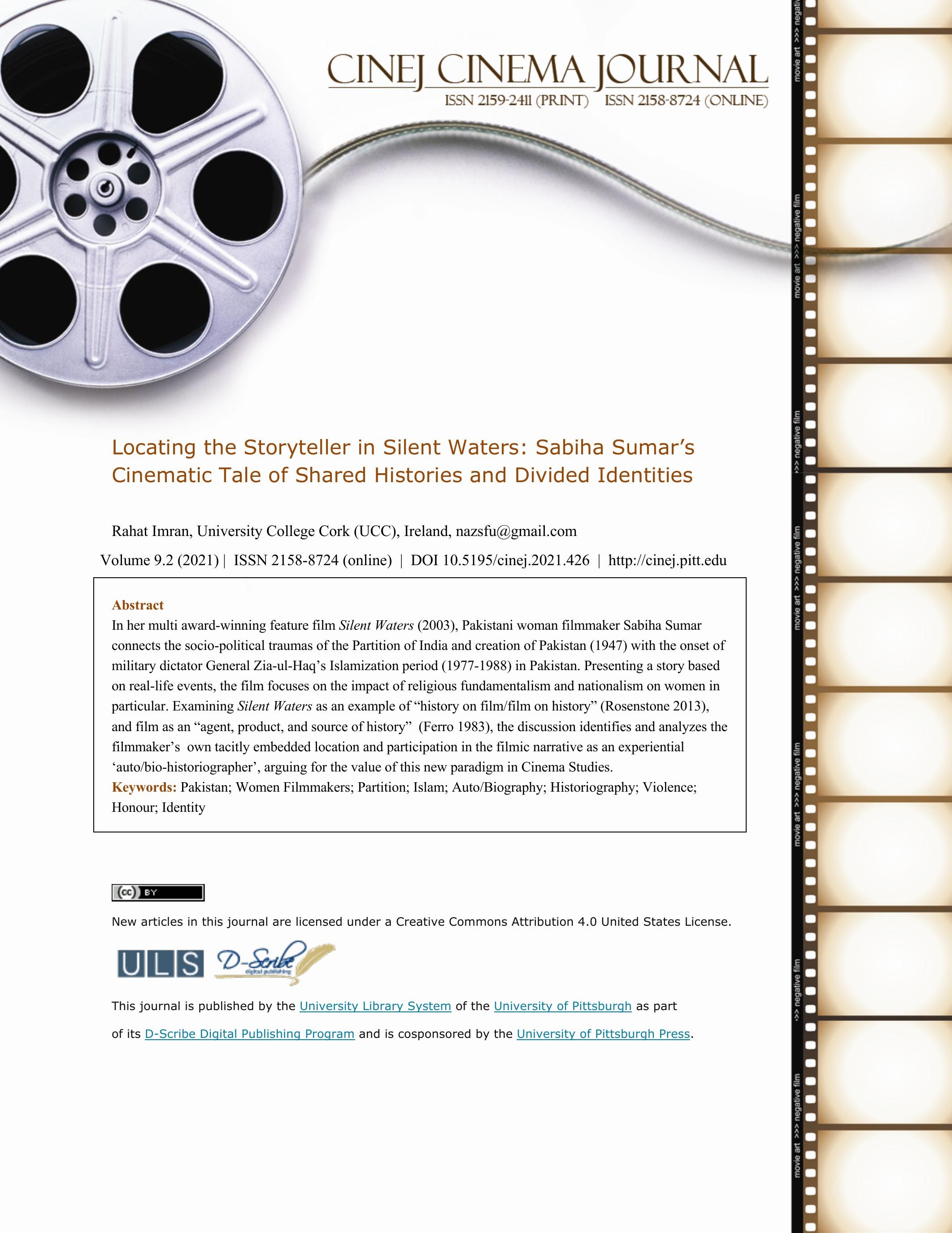




\section{Locating the Storyteller in Silent Waters: Sabiha Sumar's Cinematic Tale of Shared Histories and Divided Identities Rahat Imran}

"Film does more than want to teach the lesson that history hurts; it wants you, the viewer, to experience the hurt (and pleasures) of the past."

$$
\text { (Rosenstone, 2013) }{ }^{1}
$$

'You are free; you are free to go to your temples, you are free to go to your mosques or to any other place of worship in this State of Pakistan. You may belong to any religion or caste or creed -- that has nothing to do with the business of the State.'

Mohammad Ali Jinnah, August 11, $1947^{2}$

'I have a mission, given by God, to bring Islamic order in Pakistan.'

General Zia-ul-Haq, April 15, $1978^{3}$

\section{Introduction}

Auto/biographical cinema — cinematic personal histories spanning first-person documentaries,

features, auto-fictions, diaries, and essay films — remains, despite its generic diversity, a comparatively peripheral arena within Cinema Studies. The limited critical purchase of auto/biographical cinema is even more pronounced for non-Western women filmmakers working within this field. For practitioners from the Islamic world especially, specific religious circumstances, alongside interconnected restrictions concerning gender, influence the telling, as well as the funding, circulation, and exhibition, of cinematic life narratives. ${ }^{4}$ Precisely because cinema spells multi-level public exposure, it augurs, for Muslim women filmmakers and their Muslim female subjects in particular, a unique form of public exposure to conservative socio- 
cultural and religio-political environments. For filmmakers and their subjects, these contextual factors regulate their public participation and freedom of expression according to the parameters of religion (Islam) and gender-specific "spatial boundaries" (Mernissi, 2003: 489), as prescribed by various Islamic cultures and states, especially those governed by orthodox Sharia laws. ${ }^{5}$ Such constraints and limitations undoubtedly also prohibit particular aspects of personal narratives and representations of the self, which may be deemed 'taboo' in Islamic cultures, not least including physical love and sexuality.

The matrix of exposure and repression renders certain things possible and certain things impossible, both on- and off-screen. The relative paucity of comment about auto/biographical cinema is striking, especially given the form's ability to present individual lives within complex historical networks, and to crystallize relationships between filmmakers, audiences, and cultures more broadly. On-screen, auto/biographical histories have the capacity to reflect not only developments in the individual and personal lives of the protagonists/characters: insofar as they interweave historically nuanced narratives—collective and plural; national and regional—such films position the filmmaker herself in relation to her choice of topic, themes, and mode of filmic expression. Off-screen, the filmmaker's own lived and embodied experience (historical; autobiographical; gendered) may be submerged in depicted stories and histories, becoming an integral part of the filmic narrative. The storyteller herself may be tacitly located within the 
manifold historical layers of a thematic or historical portrayal. Hence, opening up to the wider, multifaceted critical turn to studying "life" in the humanities, I use the term "auto/biography" in this paper to explore how the porous boundaries of such work "disrupts conventional classifications of life writing, disputing its divisions of self/other, public/private, and immediacy/memory" (Stanley, 1993: 41).

It is difficult to overestimate the varied achievements of Muslim women filmmakersconsidered both within their own national cultures and in terms of a global diaspora - in bringing women's life stories to the fore. In claiming the right to portray their subjects' and their own lived experiences as witnesses from a gender-specific, often explicitly "feminist standpoint" (Hartsock, 1998: 107), while also balancing their own religious identities (especially as they critique marginalizing Islamic doctrines), the cinematic representations in question constitute a significant symbolic realization that treats a woman's testimony as half that of a man's (Mumtaz and Shaheed, 1987: 106), which is made especially grave given the constraints placed on women's testimony under the Sharia Law of Evidence. Cinema, with its benefit of "mimetic immediacy" (Everett, 2007: 128) moreover affords Muslim women filmmakers an equalizing platform to be their own witnesses; to reach receptive cross-cultural audiences through global screenings and exhibition opportunities at international film festivals. 
However, although Muslim women filmmakers - here positioned as "insiders"-are grounded in the history, languages, and religious contexts of their respective countries and cultures, living through all of the implications, restrictions, and nuances that accompany such positions, studies pertaining to their status as experiential and auto/biographical filmic historians remain absent in the discipline, as do critical insights into the wider significance (or indeed limitations) of their revisionist representations (Minh-ha, 1991: 65). To this end, a meaningful examination of auto/biographical cinemas produced by Muslim women filmmakers must contextualize their filmmaking practices with regard to the specificity of the regional, historical, religious, and socio-political environments from within which their productions originate. Only thus might scholars identify and evaluate the form of auto/biographical positioning that also locates them as filmic historiographers who bring crucial yet neglected accounts from their societies and regions to public notice (Renov, 1993: 27).

Taking an interdisciplinary approach that draws on a range of secondary sources, this essay discusses the Pakistani Muslim woman filmmaker Sabiha Sumar's multi award-winning debut feature film, Silent Waters (2003). Based on real-life events, the film examines the repercussions - both historical and personal—of the Partition of the Indian sub-continent (1947), tracing the lingering religious complexities and gendered impacts of Partition during the highly 
charged environment of Pakistan's Islamization period under the military dictator General Ziaul-Haq (1977-1988).

Silent Waters's critique of divisive religious ideologies, misplaced nationalist sentiments, and shallow pride extends indeed to Sumar's decision to use a Pakistani/Indian cast. Choosing an Indian Punjabi Sikh actress, Kiron Kher, to play the Sikh/Muslim protagonist Veero/Ayesha, the filmmaker makes a strong case for revisiting shared histories and divided identities, calling for a humane look at the struggle for independence, the trauma of the Partition, and the mass migration and violence that followed in its wake. Endorsed by the Human Rights Watch (HRW) as part of their Human Rights DVD film collection, Silent Waters testifies to the untold and uncounted stories of women who suffered gendered violence, sexual abuse, abduction, and forced religious conversion during the Partition, on either side of the new Pakistan-India borders. ${ }^{6}$

Screened at the 2004 Sundance Film Festival, Silent Waters garnered 16 awards worldwide, taking prizes from film festivals in South Africa, France, Argentina, Germany, and Australia. At the Locarno International Film Festival, the film won the Golden Leopard Award for Best Film, and a Best Actress Leopard award for its lead actress Kiron Kher, besides three other awards. It was also the first Pakistani film in 35 years to be released commercially in India. By means of 
travelling screening units, the film was screened in 41 villages and towns across Pakistan, generating a national discussion on the lasting impact of the Partition (Shaikh, 2005). However, mainstream cinema screenings in Pakistan have not taken place, most likely owing to the film's sensitive religious themes.

Silent Waters demands a contextual analysis of its intersecting themes - the Partition of India, Islamization, religious fundamentalism and nationalism, politics, patriarchy, honour, gendered violence, identity, memory, and trauma - to examine the multi-layered complexities of the shared histories and divided identities that are at the core of its narrative. ${ }^{7}$ This discussion examines Silent Waters against Rosenstone's framework of "history on film/film on history" in order to consolidate Sumar's position as a filmic historiographer (2013: 181). This essay considers Silent Waters as an "agent, product, and source of history," in all its layers and levels of representation (Ferro, 1983: 358). It furthermore addresses the socio-political and cultural location of Sumar as a Muslim woman filmmaker, whose invisibly entrenched participation in the film's representational framework is reflective of her own discreetly embedded historical and experiential positioning as a filmic auto/biographical-historiographer from the Islamic world.

This essay begins by offering a brief historical background to the Partition of India and creation of Pakistan in 1947, thereby outlining the nature of gendered violence committed during this phase on the pretext of "national honour" and religious identity. This essay then tracks the advent 
of Islamization and its ensuing environment of religious intolerance in Pakistan, as depicted in the film's 1979 setting. ${ }^{8}$ A discussion of the memorialization of Partition, pivoting around firsthand accounts and the missing role of women, is followed by an extended contextual reading of Silent Waters, its various themes, and its significance as history on film/film on history. Finally, the discussion traces and links Sumar's identity as a Pakistani Muslim woman and her position as a filmic historiographer implicitly embedded in her own film. The essay thereby identifies a filmic auto/biographical and historiographical impulse in Silent Waters, where the shared historical experiences of the filmmaker or storyteller converge discreetly at various points with the timeframes and experiences of the characters in the film, creating a singular paradigm that I suggest can be seen as filmic "auto/biographical-historiography".

\section{Partition in its Historical Perspective}

In 1947, growing resistance to British colonial rule in India resulted in its independence and partition on religious grounds by Viceroy Lord Mountbatten, who termed the event the largest administrative action in human history. The event, usually simply termed Partition, also resulted in the creation of the new Muslim state of Pakistan, led by its founder Mohammad Ali Jinnah who envisioned the country as a secular state that would guarantee religious freedom to all. ${ }^{9}$ Partition saw the division of the provinces of Punjab and Bengal between the two newly 
independent states (Khan, 2017: 88). Although Pakistan was created in the name of religious identity as a Muslim majority state, it also consisted of various minority religious groups including Christians, Sikhs, and Hindus who chose to stay on in their ancestral regions and communities in the new country. ${ }^{10}$ However, despite their new status as Pakistani citizens, these minorities were — and have remained — at the receiving end of socio-political discrimination and communal violence. Maria-Magdalena Fuchs and Simon Wolfgang Fuchs (2020) elaborate their post-partition predicament:

Beyond being an (uncomfortable) reminder of a shared past, or alternative possibilities of shared spaces, Christians, Hindus and Sikhs—-notwithstanding their small number-constitute a further challenge. They symbolise the category of "enemies from without" who present a threat of other allegiances towards the central idea around which Pakistan is constructed, such as a tenuous suppressed memory of colonialism and imperialism (in the case of Christians) or communalism (in the case of Sikhs and Hindus). Their continued existence could thus be seen as an "intolerable deficit in the purity of the national whole" that has the potential to elicit the Muslim majority's "rage". (64)

Partition generated communal violence of a horrific magnitude as India and Pakistan became sovereign states (Saksena, 1990: 14). The administrative rupture saw the largest migration in human history when an estimated fifteen million uprooted people, most led by religious identity, 
crossed the borders of both countries to find their new homelands (Talbot, 2000: 134). Families were divided either through bloodshed, or through economic and social upheaval, leading to personal losses and emotional traumas that, for many, have lasted ever since. Although the migration process was not carried out in a time of war or armed conflict, communal violence claimed over one million lives, with women being prime targets of rape and sexual violence by opposing sides as from the patriarchal perspective they have traditionally been seen as symbolic repositories of religious, tribal, community, and national identity and honour. ${ }^{11}$ Hence, the defilement of women's bodies through sexual violence was seen as a symbolic debasement and sullying of the community they represented. Khan (2017) points out that during Partition "rape was used as a weapon, as a sport, and as a punishment...It sparked the deepest feelings of revenge, dishonour, and shame" (133). Thus, sexual violence against women during Partition was inflicted to abase the men and honour of the rival religion as "a woman's body became a site where one group tried to prove its religious supremacy over the other," (Dey, 2017: 107). Ramchandra Guha (2007) states: Unquestionably the main victims of Partition were women: Hindu, Sikh and Muslim...Women were killed, maimed, violated and abandoned. After independence the brothels of Delhi and 
Bombay came to be filled with refugee women, who had been thrown out by their families because of what someone else had done to them against their will. (107)

Trains piled with dead bodies crossed into the newly-independent states, "blood seeping from under their carriage doors" (Hajari, 2015: 16). Bodies of women who had been raped and killed, including many with mutilated breasts and others bearing the tattooed names of their rapists, were transported as emblems of hatred and victory, won through bloodshed, stamped by the male power of Hindus, Muslims, and the Sikhs from both sides of the divide (Talbot, 2000: 157). It is estimated by Ishtiaq Ahmed (2002) that, in all, 75,000 women from both sides were raped (10-11). Jaswant Guzder (2011) noting:

Acts of aggression during the partition were frequently acted out on the bodies of women or in other ways displaced onto women, who have carried identity and embodied historical memories that resonate with a long legacy of conquest and rape on the subcontinent as power changed hands. (587)

Following the Partition, members of the Sikh population in the Indian East Punjab were particularly affected as their holiest site of pilgrimage, the Nankana Sahib (the birthplace of the founder of the Sikh religion, Baba Nanak), and other significant temples, known as gurdwaras, were located within what became Pakistani territory in West Punjab (Khan, 2017: 97). Despite political tensions that have affected travel between Pakistan and India since Partition, the Sikh 
population has retained a deep bond with Pakistani soil through pilgrimages to sacred sites

(Singh and Fair, 1999: 253). As the worldwide Sikh community campaigned for the right to visit such holy sites, the government of Pakistan granted permission for annual pilgrimages in 1975. This relaxation in travel restrictions was a significant development in the strained history between the two countries, who fought two full-fledged wars in 1965 and 1971, the latter resulting in the secession of Pakistan's East Wing that is today Bangladesh.

After independence, armed forces in both states built reputations for heroism during these wars, cementing their ongoing status as upholders and guardians of the partitioned national borders. Nationalist imaginaries have been further compounded by the regular invocation of religious fervour (particularly that which pits Muslims against Hindus), further dividing the neighbouring countries along the lines of religious identity and closely related political interests, all of which have fomented a mutual image of each country as the other's "enemy". South Asia political analyst Ishtiaq Ahmed (2002) attributes this matrix of hostilities to a system of "pathological politics" in which the two countries have been mired since Partition (9). ${ }^{12}$

In July 1977, thirty years after Partition, General Zia-ul-Haq usurped power from elected Prime Minister Zulfikar Ali Bhutto, instating a Martial Law regime that lasted 11 years (19771988). The General claimed he had been ordained by "divine powers" in a dream and tasked 
with bringing an Islamic order to Pakistan (Alavi, 1988: 64). To achieve this goal, he launched a fundamentalist Islamization process to transform the country on the pretext of an "Islamic identity", promulgating Sharia laws and rigid state policies, including draconian sanctions such as stoning to death for extra-marital sex (Zina Hudood Ordinance 1979), a maximum prison term of 25 years, and a further punishment of 30 lashes. The Blasphemy Law was revised to carry life imprisonment and the death penalty for blasphemy through the respective implementation of sections 295-B (1982) and 295-C (1986). The Law of Evidence (1984), moreover, rendered a woman's testimony as being worth half that of a man's in the court of law (Imran, 2008: 122). While women were used as symbols of honour, they were marginalized as citizens and their status as legal equals was corroded. The Islamization period is etched in Pakistan's history as a gravely regressive epoch that sought to reverse secularism and curtailed women's rights, while promoting fundamentalist ideologies through madrasas (religious seminaries) operating under state patronage. The impact of these policies contributed to a rise in religious extremism including anti-West jihadist and terrorist ideologies such as those promoted by the ultra-militant Taliban and Al Qaida terrorist factions (Hussain, 2007: 78).

\section{Retrieving the Past}

The passage of over seven decades since the Partition of 1947 has seen the number of witnesses and survivors of its violence steadily dwindle, especially in recent years. Across Pakistan, India, 
and their many diasporas, however, the topic inevitably rekindles old wounds for many, even at today's historical distance. Writers, academics, and historians in both countries have explored the historical evidence, alongside government reports and data, to address the Partition's political ramifications and foreground issues of trauma and personal loss. Partition Studies has emerged as a discrete field, as indeed has Partition Literature. Auto/biographical, oral, and fictionalized narratives have all served to recall the horrors of the event (Didur, 2006). To date, however, women-centered cinematic representations of the Partition remain comparatively few.

"We memorialise to remember, but memorials are stone", Nigel C. Hunt (2002) points out: "[commemorations] make memorials human[;] [enabling] us to recall the past" (200). Despite the scale of human loss, displacement, and sacrifice during Partition, there are no public memorials in Pakistan or India to humanize - nor even publicly commemorate - the event, nor to pay tribute to the casualties of mass migration (Khan, 2017: 201). In both India and Pakistan, "Independence" days are celebrated, lauding the sacrifices made for liberation from British colonial rule, but there is a conspicuous absence of any public monuments dedicated to the suffering occasioned by Partition. As Urvashi Butalia (1998) elaborates:

The suffering and grief of Partition are not memorialized at the border, nor, publicly, anywhere else in India, Pakistan and Bangladesh. A million may have died but they have no monuments. 
Stories are all that people have, stories that rarely breach the frontiers of family and religious community: people talking to their own blood. (52)

Although the Partition was not the result of a war, violence and murder were committed, as the above outlines demonstrate, on a colossal scale. No truth-finding commissions nor human rights tribunals were constituted to attribute accountability for these crimes, however. In the absence of such measures, and of public monuments, writers and artists have taken it upon themselves to tell stories otherwise fated to pass away with first-hand witnesses and survivors. Partition literature (novels; short stories; plays; poetry) in both countries has, no doubt, imbued the subject with officially marginalized political and religious perspectives: victorious tales of political struggle and independence; nostalgic stories of lost homes and relationships; hopes and dreams of better tomorrows; bitter remembrances of betrayal and treachery; and tales of remarkable friendships that stood the test of times and circumstances. Even as these narratives recall the monumental tragedies of the event, however, women's auto/biographical stories remain scant. Lacking representation both in official memorials and in literary culture, therefore, acknowledgements of the sexual and communal violence suffered by women during the Partition are doubly absent from public space. Bharati Sadasivam (2004) elaborates on this glaring void in her article: 
The official record of 1947 is largely silent on how women and children experienced the trauma of the time. It was not until the 1990's, when Indian writers such as Urvashi Butalia, Kamla Bhasin and Ritu Menon began to excavate women's experiences in writings that were part memoir, part research and part journalism, that the wrenching stories of women began to come to light. (Frontline Magazine).

Recent practices have sought to redress this absence. Further to the pioneering non-fiction works of women writers Ritu Menon, Urvashi Butalia, and Kamla Bhasin, focussing on women's experiences of the Partition, and the success of women literary authors like Bapsi Sidhwa (IceCandy Man), Amrita Pritam (Pinjar), Anita Desai (Clear Light of Day), and Shauna Singh Baldwin (What the Body Remembers), a focus has developed on unearthing, recording, and archiving oral stories, interviews, photographs, collection of personal items and artefacts. This has been an institutional as well as a personal labour. Online lists of films, books, and archives from survivors of the Partition period are made available by the Citizens Archive of Pakistan (Oral) History Project under the patronage of Pakistani woman filmmaker Sharmeen ObaidChinoy. Other invaluable resources include the 1947 Partition Archive and the project, Preserving Memories of Partition of India. The Partition Museum in Amritsar, India, is the first repository to commemorate Partition through refugee artefacts, art pieces, oral stories, and 
archival material. The Kolkata Partition Museum based in Kolkata, India, commemorates the Partition of Bengal.

What role has cinema played in this outbreak of commemorative practice, however?

Cinematic representations of the Partition era have remained at best nominal in both Pakistan, and India, despite otherwise thriving mainstream film industries (India's is the world's largest).

Films that do address Partition typically project a patriotic picture, and feature male protagonists as saviours of national and religious honour and identity. ${ }^{13}$ In Silent Waters, however, Sumar focuses on a fictionalized biographical story of a woman from an historiographical perspective that questions the historical narrative of foregoing cinematic portraits.

\section{Silent Waters: A Tale of Shared Histories and Divided Identities}

Set in 1979 during General Zia-ul-Haq's dictatorship and the introduction of his Islamization process across Pakistan, Silent Waters is a fictionalized life story of a Sikh woman, Veero, who converted to Islam during Partition, taking on the Muslim name of Ayesha after marrying her

Muslim abductor. The use of the Punjabi language at once situates the filmic events and characters geographically and culturally, in the post-Partition Pakistani province of West Punjab.

The film opens in the peaceful setting of the village of Charkhi, where Ayesha (Indian actress Kiron Kher), a middle-aged widow, is shown as a fairly happy and peaceful woman, referred to 
affectionately as "Ayesha chachi" (aunt) by the children to whom she teaches the Quran. Her only child, Saleem (Aamir Ali), is shown as a dreamy, lazy, romantic unemployed youth, more interested in playing the flute and wooing a teenaged schoolgirl, Zubeida (Indian actress Shilpa Shukla) than his future career prospects. Scenes of routine village life show Ayesha mixing freely with neighbours who show fondness for her. Dancing and merrymaking at a village wedding convey the relaxed and close ties of life in Charkhi. Sumar, however, quickly establishes the reluctance of her protagonist (Veero/Ayesha) to go to the village well, showing how her friend Allabi (Tasleem Bibi) is called upon to fetch her water. This disarming detail is to become central to the theme and events of the film as its narrative unfolds.

Sumar establishes a parallel storyline in the first half of the film by inserting four intermittent flashback scenes sharing common elements (a well, running feet, a train) to establish a link between the past (Partition in 1947) and the film's present (Islamization in 1979). As these ties are constructed, Veero/Ayesha's fragmented memories continue to haunt her. Making a link with the Partition, a first flashback shows young girls running around a well as we hear Ayesha's weary voice-over: "Summer days in 1947 seemed so much hotter. How we ran. How did we know that it would be forever?"14 The scene ends with a focus on running feet and the sound of a 
passing train in the background. A second flashback to the well, clouded by dust sweeping across the landscape, is accompanied by Ayesha's remorseful voice-over:

Two countries were born. Men abducted women. Fathers killed their daughters. Everyone said it was to save their honour. Some young girls died, others survived. People moved like the sea...leaving everything behind. Broken memories, half-dreamt dreams, places of worship.

The third flashback shows the village well with a young girl standing at its edge looking down into the deep waters, followed by images of running feet and the sound of a passing train, evoking the role that such vehicles (also referred to as "blood trains") played in the communal violence and massacres committed during the migratory process in the wake of Partition. This time the flashback appears as Ayesha lays her head on the pillow to sleep at night, and is unaccompanied by dialogue. The fourth flashback again appears in the deep quiet of the night as Ayesha's day is done and she prepares for bed. Developing the narrative, this time we see images of a young girl running before she is intercepted by a group of men who take her away forcibly.

The calm village setting takes a sudden turn as two Islamic preachers, Rasheed and Mazhar (Sarfaraz Ansari and Adnan Shah Tipu), arrive from Lahore city in the midst of a wedding celebration shot through with jovial merry-making, drinking, singing, and dancing, and attended by Ayesha and Saleem. The cheerfulness of the wedding scene is contrasted with Rasheed's 
deeply conservative and disapproving views on the celebrations, boding the unpleasant situations to follow.

At a congregation in the local mosque, the preachers begin to cultivate and conscript men to join them in their mission: to establish General' Zia's Nizam-e-Mustafa, ridding the country of the "darkness" in which it is enshrined, on account of widespread immoral practices, and steering it towards an Islamic path. ${ }^{15}$ We see Saleem and his friend in attendance as the preacher rallies for support. In the next scene the local postman, Amin (Salman Shahid), informs Ayesha that the deposed prime minister Zulfikar Ali Bhutto, previously under trial, has been hanged by the Zia regime. ${ }^{16}$ Both developments signal Zia's authoritarian political grip and the nationwide launch of his Islamization process.

Influenced by Rasheed's rhetoric of pursuing a "holy mission to save Islam," Saleem and his friend accompany him to a religious gathering in Rawalpindi where an inflammatory sermon endorses waging jihad (holy war) against "infidels" to uphold Islamic values, reminding attendees of the Partition, and the creation of Pakistan as an "Islamic" state, and claiming that the "border demarcation lines" were drawn from sacrifices made by "Muslim blood."17 Lambasting women for not covering their heads, and castigating entertainment through film and television as 
the obscene work of the "devil," the speaker upholds General Zia as a saviour who can guide the nation, through Islam, towards salvation.

By the time of his return to Charkhi, a visibly changed Saleem has joined the fundamentalist preachers in their mission. Saleem's journey is indicative of a common trend during the Islamization period, when young unemployed men were recruited to fight "infidels" (a label that extended to all non-Muslims) by representatives of religious parties. We soon see the radicalized Saleem participating in raising the height of the wall around the village's girls' school, a putative attempt to "protect" women in line with the concept of "chador and chardiwari" (segregation and four walls) advocated by Zia. ${ }^{18}$ As his association with the preachers strengthens, the distance between him and his mother, and with Zubeida, deepens. As an acutely disturbed Ayesha finds leaflets in Saleem's drawer from the religious congregation he secretly attended in Rawalpindi, a fifth flashback presents images of a girl being dragged out of a hut by a man, indicating likely sexual violence inflicted by her abductor.

Confronted by Ayesha about his visit to Rawalpindi, Saleem tells his mother that he has found a focus and aim in life. Disturbed at the radical transformation in her son's attitude, Ayesha cautions him about associating with the preachers, calling them "political types" and “dangerous people who trade God's name for their own ends." She warns him that this affiliation will “destroy our lives.” In response, a defiant Saleem tells her she should be proud of him 
because he has found respect and position and now feels like a "somebody [...] People listen to me now".

In the midst of the turmoil brewing in Ayesha's relationship with Saleem, her life is further shaken up when a group of Sikh pilgrims from India arrive in Charkhi, their pre-Partition ancestral village, to celebrate a holy festival in the Sikh gurdwara (temple) of Punja Sahib. Scenes of the pilgrims' train arriving at the railway station, of men in Sikh turbans, and of devotional activities in the Sikh temple, altogether evoke a pre-Partition Punjab, while conjuring up memories, for both sides, of the violence and personal losses that followed. The sight of the Sikh pilgrims in their turbans marks a clear religious divide between the host Muslim state of Pakistan, now in the grip of a volatile process of "Islamization", and the arriving devotees in search of spiritual peace and guidance. Their entry is met with hostility and ridicule from the radical Muslim elements in Charkhi who openly incite hatred toward them as kafirs (infidels). Bitter memories of the violence, rapes, and massacres committed during the Partition begin to simmer anew, as deep-rooted religious and political resentments swell. As Ayesha sends sweetmeats to the gurdwara for the pilgrims, her gift is intercepted by Saleem who denounces her extension of hospitality to the village's Sikh visitors: "Do you know the punishment for associating with infidels?" Ayesha retorts ironically that not so long ago the infidels had been 
like "brothers". Smashing the container of sweetmeats, Saleem warns her that her acts of hospitality could have damning consequences.

The boiling point of these tensions turns, appositely, on the remembrance of gendered violence during Partition. Speculating among themselves as to whether any Sikh women left behind in Charkhi may have survived, one devotee insists that all 22 women had been shot dead at their own request, in order to avoid abduction by Muslim men: "We did not let Muslims touch them. Our honour was saved." ${ }^{\prime 19}$ Belying this narrative, the film's sixth flashback duly appears, showing a young girl being slapped by a man who calls her the daughter of an "infidel". The girl is rescued, or rather abducted, by another Muslim man, whom we are invited to imagine as the one who would come to marry Veero/Ayesha.

As if seeking to confirm the flashback's suggestion, one Sikh pilgrim, Jaswant (Indian actor Navtej Johar), decides to trace a lost sister, Veero, whom he remembers had refused to jump into the well to save the family "honour" ${ }^{20}$ Breaking his silence about Ayesha's Sikh identity, Amin (the postman) apprises Jaswant of her whereabouts, identifying her as "the one who never goes to the well". With this terse identification, Sumar furtively points to the absence of national or trans-national memorialization of violence against women during Partition. Instead of being a "site of memory" for the community, the well operates, ironically, as an unmarked functional physical space in the film (Nora, 1989: 7). Only Veero/Ayesha's refusal to go to the well 
indicates otherwise. Tracing Ayesha's house, Jaswant asks her about his sister "Veero" who, he says, was left behind during the Partition. As Saleem arrives at this highly tense point in the film, he snatches a locket from Jaswant's hands, presenting it as evidence of his lost sister.

Discovering his mother's picture in it, Saleem demands her to tell the truth. Calling her "Veero," Jaswant tells Ayesha of their dying father's wish to see her once more. Enraged, Saleem exclaims that his mother is the "sister of a kafir" (infidel): "What should I do?" he asks, to which a visibly traumatized Ayesha replies impassively: "You don't need to do anything".

As word gets out about Ayesha's association with Jaswant, the preachers confront Saleem and warn him of the consequences if his mother does not publicly declare her allegiance to Islam: "Otherwise we will have to report the matter to Lahore", threatens Rasheed. Saleem demands his mother to comply in order to salvage the family's "honour," forcing upon Ayesha a dilemma of the very same nature as the one she had faced during Partition.

The imposition, whereby Ayesha is - for the second time-compelled to bear the burden of religious intolerance, is mirrored in a scene involving another, younger woman. With newfound religiosity, Saleem abruptly ends his relationship with Zubeida, telling her that she is "corrupting" him and informing her of his decision to go to the city to "serve his country". As he leaves for prayer, Zubeida retorts: “I also pray but that doesn't mean I don't think”. Her curt 
remark encapsulates the growing chasm between Zia's fundamentalist ideologies, and the emerging pockets of resistance that rejected his agenda, led, significantly, by women's organizations. $^{21}$

While neighbours begin to shun Ayesha, the previously convivial Allabi also refuses to bring her water from the well. "I will have to go myself to the well", utters a dejected Ayesha. The seventh sepia scene inserted here shows Veero looking down into the well. ${ }^{22}$ Flashbacks show Sikh men hurriedly urging girls to jump into the well: "the Muslim men are coming after us". As girls are thrown underground, we see one run away from the scene, pursued by a young Sikh boy calling after her, "Veero". In his failed attempt to seize her, the boy catches hold of her locket. The girl is no sooner seen captured by a group of Muslim men.

Locating Ayesha at the same well where they had separated during the Partition, Jaswant asks her to return to India to see her ailing father for a final time. Bitterly, Ayesha responds: So he can finish the job? Wasn't killing mother and Jeeto enough? He wanted to kill me for his peace. What will he do if he sees me alive and a Muslim? How will he go to his Sikh heaven? And what heaven is there for me? A Sikh heaven or a Muslim heaven? You were happy to think I was dead. But I am alive. I made my own life, without you. Now this is my life and my home. Go away. Leave me the way I am. 
Here, the final flashback concludes the parallel storyline, showing Veero married to her Muslim abductor as a Muslim priest proclaims off-screen: "From this day on, your Islamic name is Ayesha".

Back in 1979, Ayesha finds herself in the midst of dramatically altered circumstances, with latent hostilities verging on open aggression towards the Sikh pilgrims. Saleem's fundamentalist tendencies are intensifying, while Ayesha is shunned by neighbours who now consider her a dangerous and alien element polluting the village. A lifetime of friendships and associations have been abruptly replaced with an environment of suspicion. Ayesha, however, decides to exercise her choice once again, refusing to be constrained by her son's demands. Asked to proclaim her allegiance to Islam publicly, there are no scenes of emotional chaos, loud emotional dialogues, melodramatic vows or assurances, no pleas for divine mercy. Instead, hers is a silent exit that demands nothing from others, blaming no-one. Donning a locket she had kept hidden in her box, Ayesha says her final namaaz (Muslim prayer) at dawn while Saleem sleeps, rolls her chador (shawl) in the prayer mat, symbolically winding up her life as a Muslim, and quietly makes the journey to the well. Entrapped, betrayed, and victimized by her past and present religious identities, we see Ayesha as a solitary figure standing at the edge of the well in the dawn light, the precipice symbolizing her isolation and predicament. Offering herself to be consumed by the 
same well from which she had escaped as a young girl in 1947, Ayesha now jumps, joining her mother and sister in death. In ending her life in the silent waters of the well, Veero/Ayesha defiantly rejects the patriarchal value system that inscribes notions of national and religious "honour" on women's bodies. Veero/Ayesha's silenced past, along with those of the other Sikh women and girls whose lives ended in the well, is articulated through this final, paradoxically "silent" act. The poignancy of the scene is clear, as Sumar draws attention to the innumerable, undocumented Partition stories of "destituted" women lost to time (Menon and Bhasin, 1997).

The film carries on, however. We see Saleem wind up his relationship with his mother after visiting Ayesha's memorial in a Muslim graveyard. Placing in her small bag his mother's few belongings, including her copies of the Quran and the Sikh prayer book (Gutka), he also adds a picture of himself, symbolizing a self he has discarded. The small bag floats away in the stream: a farewell to Ayesha's identity, and to the maternal presence that may have hindered Saleem's own progress and position in the fast-changing Pakistani socio-political milieu. ${ }^{23}$ Absolved of possible "consequences", he is now free to follow his ambitions.

Concluding another farewell, Saleem hands over Ayesha's locket to Zubeida, the final material reminder of her past, saying simply: "It is for you". In voice-over, we hear Zubeida pondering: "So this is how Veero left and Ayesha stayed behind—do we know who left and who 
stayed behind?" The silence meeting Zubeida's question resonates with the secrets buried in the village well, and scattered throughout the post-Partition sub-continent.

Sumar ends Silent Waters 23 years later, in 2002. The setting is the city of Rawalpindi. Having usurped power from the democratically elected prime minister, Mian Nawaz Sharif, another military dictator, General Pervaiz Musharraf, is ruling the country and serving as a US ally in its post-9/11 "War on Terror" (Grove 137).

In the concluding scene we see Zubeida as a young woman who has apparently progressed professionally. As she puts around her neck the locket that carries the picture of Ayesha as Veero, Zubeida muses in voice-over about the nature and limits of remembrance: "I remember Ayesha chachi very clearly. But what is the point of remembering her? Does it change the price of onions? Sometimes she comes in my dreams. I preserve each and every dream so they never leave me". As she heads out into the street, an image playing on a TV screen in an electronics shop catches her attention. Closing in, we see numerous screens airing an interview of an older and heavily bearded Saleem who, as an established politician and Secretary General of a radical Islamic party, is offering his views on religion and politics. Saleem is interviewed against the backdrop of the iconic Faisal Mosque in the capital city of Islamabad, conveying the political prominence he has attained through his allegiance to religious nationalism, a hallmark of 
fundamentalist power networks in Pakistan. Amused, Zubeida turns her back on his image, and walks away. Her silent but unmistakable dismissal of religious chauvinism and zealotry, whose authority is symbolized in the multiple screens depicting Saleem, is reminiscent of Ayesha's final act. Embedded symbolically in Zubeida's reaction, Sumar conveys her own generation's oppositional stance against religious fundamentalism, recalling her foray into activist filmmaking with her first documentary, Who Will Cast the First Stone? (1988), a critique of Zia's Islamization and its imposition of gender-discriminatory laws. ${ }^{24}$

\section{Religion, Identity, and Honour}

Religious honour and national identity have remained entwined and contentious issues in postPartition Pakistan and India, as state borders continue to play the role of gatekeepers of religious "purity" (Sundar, 2010: 288). Ayesha's multiple, and yet static, acts of border-crossing alter her national and religious identity as she converts from Sikhism to Islam in 1947 Charkhi, a village thereafter demarcated within the Islamic state of Pakistan. Her escape from honour-killing during Partition now reconfigures her status as an inhabitant of an Islamic country in West Punjab.

Ironically, even without the violence that accompanied physical migration, her fragmented identity bears important implications for religious nationalism in the rapidly changing Islamization environment of 1979 in Pakistan. Once her Sikh past is discovered, her national 
identity, religion, marital status, and status as a mother become suspect and questionable. Asked by her son, newly ensnared by religious nationalism, to publicly declare her religious identity as a Muslim, Veero/Ayesha finds herself betrayed and isolated at the threshold of a dangerously minoritized status within her community and country, her identity besmirched in unforgiveable impurity as an 'infidel'. In this life narrative, identity is revealed to be determined by both nationhood and religion. Seen now as a mere symbol of 'dishonour', whose Sikh past stands to tarnish her radicalized Muslim son's future in a growingly fundamentalist environment, Ayesha is robbed of choices to stand her ground within the context of her community and in the country at large.

In quietly rolling up her chador in her prayer-mat, Ayesha signifies that she no longer has any use for a singular religious identity. A personal, private, political and national history (as Indian/Sikh, Pakistani/Muslim) is rolled into the prayer mat; her final journey to the well brings to an end a traumatic past, hostile present, and uncertain future commanded by men, patriarchy, religion, and the ideas of "honour" violently marshalled by others. In her decision to commit suicide, the Sikh/Muslim Veero/Ayesha frees herself of enforced identities and the personal "partition" others wish to impose upon her. In death, she chooses the one end that she herself is able to dictate. As yet another history is buried, however, Sumar leaves us pondering about the 
structural inevitability of the death. Would an earlier death for Veero at the time of the Partition have saved decades of pain and emotional turmoil? Casting herself into the same well she escaped during Partition suggests the almost preordained nature of the death, its fatally repetitious compulsion foreshadowed by the recurrent sepia-toned flashbacks that punctuate Silent Waters to reflect her deep-rooted traumatic memories of the Partition. Is death the accomplishment of a destiny Veero/Ayesha could postpone, but not avoid?

Despite a focus on tragic consequences for the protagonist, the film's insight into the structural nature of nationalist and religious violence has a trans-personal scope. Indeed, Saleem's own predicament indicates that he too is a victim of the governing orders of the Islamization period, when extremist religious ideologies and fundamentalist adherence to statesponsored radical madrasa teachings became the shortcut to an otherwise unimaginable upward mobility. The extent of Saleem's transformation under such circumstances is exemplified by the scene in which he floats away her belongings; although the act is decisive, its quiet respect for the possibility of religious difference recalls the secular, pre-Zia environment in which Saleem was raised. The sharp change in the young man's identity, however, contrasts sharply with the fate of his mother who chooses death over subjugation. As Ayesha's bag floats away with her self-identifying articles, it too will be consumed by silent waters, burying the rest of her story. 


\section{Memory and Trauma}

Post-colonial scholar Homi K. Bhabha (1967) maintains that the process of delving into the past

for answers and guidance about the present constitutes an act of remembering, one that "is never a quiet act of introspection or retrospection," but is "a painful re-membering, a putting together of the dismembered past to make sense of the trauma of the present" (xxiii). Silent Waters does precisely this. Representative of multiple layers of Veero/Ayesha's and Sumar's experiences and memories, the film subverts official and dominant discourses to journey back in time, looking for answers in the differentiating possibilities generated by film. As it does so, the film highlights the power of memory to disrupt and contradict the "linear flow of storytelling, of truth and authenticity" (Oishi, 2006: 196) just like Toni Morrison's (1995) famous image of water that "has a perfect memory and is forever trying to get back to where it was" (98-99). The filmmaker and her protagonist merge at various levels of shared historical experience, as one faces divided identities (Veero/Ayesha), and the other occupies a position as both "insider" and "outsider" on screen and off, traversing historical junctures to reach into the past's multiple points (Stanley, 1993: 46). Silent Waters, to be sure, develops a linear historical account of Ayesha's 1979 "present". The flashbacks rupture this narrative self-possession, however, and inscribe in it a past that is non-linear, and — for those who experience it—deeply traumatic, obscure, and fragmented. 
Although sepia images of the Partition period, accompanied by Veero/Ayesha's voice-over, are recalled through "common memory" that distances her from the historical event, restoring a normalcy to her post-Partition life, she is unable to distance herself emotionally when confronted by her brother. At once veering towards a wounded "deep memory" of her escape from honourkilling, she is compelled to confront Jaswant with blunt questioning of their father's actions during Partition. ${ }^{25}$ In her exchange with Jaswant, her suppressed traumatic memories of the Partition rise to the surface, and her own questioning of her identity as Ayesha confronts her 'present "I", which is invaded by the memory of a former "I" (Hirsch, 2008: 104). For her, it is time to decide on an identity: Sikh? Muslim? Indian? Pakistani? Parts of each of them, or a rejection of them all?

Silent Waters as History on Film/Film on History

Depicting various dimensions of "history on film/film on history", auto/biography and historiography, Silent Waters sees these modes merge in Sumar's cinematic rendering, simultaneously crystallizing the filmmaker's own experiential position. Appropriating film's capacity to "collapse historical time" (Rosenstone, 1995: 227), Sumar is able to both show and connect three transformative moments in Pakistan's history and in the lives of her characters (1947, 1979, 2002), reconfiguring a historical past spanning fifty-five years within a duration of 
99 minutes - a past also tacitly embedded in her own life as a Pakistani. Transferring history to film through real-life events, Silent Waters "re-visions" (Rosenstone, 1995: 171) crucial phases of the past, becoming a document of visual history in the public realm that "emotionalizes and personalizes the past" through its nuanced depictions of complex characters and their experiences, drawing viewers to participate in a past they may never know otherwise (Rosenstone, 1995: 240). Using a narrative form instead of a conventional documentary format to present historical events, Sumar presents biographical stories in flux, as characters' emotional developments are shown to be inseparable from a changing religio-political landscape. Addressing the possibility of transferring history to and on film, Rosenstone (2013) argues that "to vision history is to put flesh and blood on the past" (133). As a narrative film on a historical theme, Silent Waters deploys moving image's unique ability to render both repetition and difference. The film's singular time bodes silences that recall recurring personal and collective traumas within the very same storyline — peopled with characters, whether real or fictionalizedwhose developments and deviations are punctuated by decisive, life-changing events that emerge from the depths of the story itself and steer it to its poignant end. In light of the conspicuous absence of women's testimonial accounts of Partition, Silent Waters leaves the viewer with 
provocative leads to revisit an historic past, immersed and entangled in countless other life stories that may never be known or told.

Indeed, in the process of her changing social and personal relationships, we are able to see what Rosenstone (1995) describes as an “integrative image” of Veero/Ayesha's “interwoven” identities (60-61), as they unfold and progress through the course of the film: daughter, sister, victim of gendered violence, “abducted woman", religious convert, wife, mother, neighbour, friend, teacher, and citizen of the new state of Pakistan. Capturing emotional depths that transcend temporal, linguistic, spatial, and cross-cultural boundaries, Veero/Ayesha's biographical account assumes a universality that, as Sumar indicates in remarks collected in film's press kit, may also resonate across other conflict zones.

Film theorist Marc Ferro (1987) points out how historical films, as opposed to written accounts of history, can shape our memories of history, people, and events (81-82). Sumar's film presents an invaluable biographical counter-history from her female protagonist's point of view, inviting viewers to a humane retrospection on an entire phase of history. As Veero/Ayesha meets her Sikh brother after a lapse of thirty-two years, she asks: "And what heaven is there for me? A Sikh heaven or a Muslim heaven?" The brief exchange conjures the horrific personal aftermath and lingering traumatic memory of an entire span of regional history. As a film on history, Silent Waters' visual immediacy points, fulfilling in Rosenstone's terms (1995), to gaps in its viewers' 
understanding of the past (194). In this case, viewers are alerted to the physical and emotional vulnerability, and forms of resistance, of women like Veero and Ayesha, caught as they are in the crossfire of politicised violence and ideological conflicts beyond their control.

As opposed to written historical accounts, often required to split apart complex totalities for analytical purposes, Silent Waters is a film that depicts "history as a process" (Rosenstone, 1995: 60). It also draws attention, therefore, to ongoing, rather than distantly historical, violations of human rights, with a particular emphasis on women's treatment in situations of violent conflict. Through precise attention to details - period-specific television advertisements, time-specific costumes, nervous conversations, aggressive attitudes, religious sloganeering, opportunistic invocations of jihad - Sumar effectively recreates the tense environment enveloping Pakistan during the Islamization period. From an historical standpoint, the film genealogically traces and preserves this key period in Pakistan's descent into the religious fundamentalism that became the hallmark of a "pure" Muslim society under General Zia’s dictatorial regime.

Film scholar Chuck Kleinhans (1984) stresses the significance of a film or video work's context: the historical moment(s) in which a work is produced, distributed, and exhibited; the audiences it reaches. Kleinhans also emphasizes the need to contextualize the filmmaker's own position regarding his or her productions, that is, the relationship of the filmmaker to their political, 
personal, historical, social, and institutional conditions (320). Eve Oishi (2006) similarly

contends that "Every individual's or community's access to the past will always remain partial and mediated by political and historical circumstances" (196-197). Although it was screened in theatres in India, Silent Waters has by and large remained a film for niche international markets, accessed through special screenings and specific institutions (film festivals; academia; film clubs and societies). This is despite the film's widespread critical acclaim, its haul of awards and prizes, and the fact that, owing to lack of technical facilities for independent filmmaking in Pakistan at the time, it was produced with substantial European assistance (from France, Germany, and the UK, as noted in an interview with Shanaz Ramzi: 2003). A mainstream release within Pakistan has yet to take place. Given the country's strong tilt towards religious nationalism, this could be attributed to Sumar's critique of the Islamization period, and the film's portrayal of an Indian female protagonist whose dual religious identity remains unresolved in the film, thereby making her (and, by extension, Sumar's) identity and acceptability as a "true Muslim" and "Pakistani" questionable to conservative and anti-India audiences at home. ${ }^{26}$

\section{Locating the Storyteller: Silent Waters As Auto/Biographical-Historiography}

Coining the term "bio-film" Rosenstone (2013: 105) argues that "by focusing on the experience of individuals or small groups, film situates itself closer to biography, micro-history, or popular 
narrative history" (19). In doing so, a film can also merge with the life experiences and identity of the filmmaker, rendering the maker-I have argued — an auto/biographical-historiographer. Simultaneously divided and joined by the slash, and the hyphen in the "auto/biographicalhistoriographer" formulation, the filmmaker can be indirectly, but emphatically, present in the history and themes of their productions. Film scholar Wendy Everett (2007) writes:

Moreover, the mimetic immediacy of film images, initially perceived as a barrier to subjective discourse, now emerges as one of the strengths of filmic autobiography, since it enables the director to recreate a remembered world exactly on her/his terms, as a complex inner/outer topography, contoured by experience. (128)

A clear case-study of this topography, Sumar's Silent Waters springs from the intersection of multiple layers of auto/biographical and historiographical experience: the regional, political, and national histories of Partition and Islamization; the religio-political and gendered aspects of these historical periods; the biographical history of the film's protagonist whose life story connects, and is entrenched in, these historical moments; the filmmaker's own personal (autobiographical) and contextual (historiographical) location as the discreet storyteller within the cinematic production. Silent Waters' multivalent method thus echoes Ferro's identification of film, cited above, as an "agent, product and source of history". 
Extending the existing critical boundaries of auto/biographical representations demarcated by Liz Stanley and others, my argument is that the addition of experiential "historiography," as in the case of Silent Waters, further personalizes and intensifies the already complex nature of the filmmaker's presence. My usage of "auto/biographical-historiography" here indicates the filmic depiction of an experiential history that may also correspond - however tangentially—-to the filmmaker's own memories and autobiographical background, thereby embedding her or his position as a participant in the cinematic reconstruction of a multi-layered historical past. By this token, the apparent on-screen absence of the filmmaker can be articulated or nuanced through the backgrounds, identities and experiences of a film's characters. Auto/biographical-historiography is always collective and multiple, therefore; the crossover between filmmaker and character(s) reveals the former's experiences to be entangled with those of a generation, community, nation, gender (or a combination of any or all of these). For example, in Sumar's dedication of Silent Waters to her parents we see how her position as filmmaker is influenced by the history of Partition as experienced by a previous generation, witnessed and refracted in turn by the filmic Veero. Likewise, as indicated above, Sumar's own background as a documentary filmmaker is registered and reframed in Silent Waters' fictional telling.

Though as a feature film Silent Waters is not reliant on a singular "I," it revolves around the experiences of its undecidable female protagonist, Veero/Ayesha, a collective and plural "we" 
that representationally stands in for others with similar experiential histories. "I" is always an other for the auto/biographical-historiographer. Similarly, Sumar's lived memory of the Islamization era merges with Ayesha's experiences during the same period, accentuating the filmmaker's own autobiographical positioning in relation to her production. As numerous interviews attest, Sumar is devoid of bitterness, value-judgements, and biases, yet deeply reflective and critical. Further reflecting and repositioning this empathy, viewers see Zubeida as a compassionate and non-judgmental individual willing to stand by Ayesha in her ordeal. Zubeida represents the strong, independent-minded girls from Sumar's generation of Pakistani Muslim women, those who opposed Zia's fundamentalist ideologies without compromising their religious beliefs.

In one interview, with Martin Gani (2009), Sumar noted that during the Partition her parents had to abandon their home in Bombay (now Mumbai), India, and flee to Karachi, Pakistan. The memory is passed on to Sumar and embedded in her generation's consciousness and ethos. As a young woman, Sumar lived through General Zia-ul-Haq's Islamization period, a phase that launched her filmmaking career with the previously-noted Who Will Cast the First Stone? (1988), which was followed by two subsequent documentary films, Don't Ask Why (1999), and For A Place Under the Heavens (2003). These films, as Imran notes (2005), probe the impact of 
religious fundamentalism in Pakistan on women in particular. As she projects others' stories in her films, Sumar's work is characterized by further indirect depictions of her own life and experiences. Sumar dedicates For A Place Under the Heavens (2003) to her own daughter, Dhiya, passing on her own memories of the Islamization period to a new generation, just as Veero/Ayesha's locket is taken up by Zubeida. As Zubeida becomes the witness and guardian of Veero/Ayesha's troubled existence and tragic end, we see a fragment of a larger history preserved and memorialized in the form of this small, personal, material object, a "dedication" that makes even clearer the absence of a public memorialization of Partition. Whereas Ayesha/Veero could not escape the predicament of her situation, Zubeida manages to leave the village to make an independent life for herself in the city, signifying a new generation of Pakistani women who could, much like Sumar herself, move ahead and realize their aspirations. The combination of Sumar's own experiences of living through the Islamization period as a Pakistani woman with her depiction of the era's radical socio-political implications in Silent Waters not only render the filmmaker herself an intrinsic part of her production (as per Rosenstone's chiastic "history on film/film on history" formulation); more than that, Sumar extends her role as filmmaker to the point that she occupies the novel, multi-dimensional role of a cinematic auto/biographical-historiographer. The capacious nature of this role allows it to be recognized across other global filmmaking practices springing from various personal historical 
perspectives entrenched in complex auto/biographical frameworks that are determined by the intersecting realities of region, race, gender, and sexuality. Recalling how she conceived the storyline for Silent Waters, Sumar says as much:

When writing this story, I wanted to connect Ayesha's past with the present. Despite her best efforts to build a life for herself, her vulnerability is undiminished. Her isolation grows and deepens through the changing political climate of the country. Ayesha represents a woman caught in a conflict and as such she represents a universal dilemma. She is the woman in Bosnia, in Sri Lanka, in Afghanistan, in Iraq...Ayesha is portrayed with Sufi characteristics- an open and giving personality- whose philosophy of life is "There is no God but the sum of all Gods." This perspective comes perhaps of my own Sufi upbringing and I needed to cast a female actor who could express the essence of the Sufi world-view. Unconsciously perhaps my mother was the role model for the character of Ayesha. (Silent Waters Press Kit)

Sumar's reflections bring together shared experiences from the lives of women across the globe, women who might be portrayed or symbolized by her female protagonist. These women come from all generations, nations, socio-cultural backgrounds and historical periods. Yet, as Sumar's practice seeks to indicate, their experiences and histories find representational resonance 
in and through each other. Anything but solipsistic in nature, auto/biographical historiography is bound to echo far and wide.

Grounding the interplay between film and history, Rosenstone (1995) argues that "history does not exist until it is created. And we create it in terms of our underlying values" (59). Appropriating film's own capacity to make history, Silent Waters undeniably depicts Sumar's constructive and indeed creative take on recent history, presenting her protagonist's biographical story through the perspective of the filmmaker's own "underlying values", themselves influenced by a liberal and tolerant Sufi background (Ahmad, 2014: 153).

In a similar manner, Indian Punjabi actress Kiron Kher's comments on her decision to accept the role of Veero/Ayesha, reflecting her own historically-embedded position in the film:

My mother comes from Lyallpur in Pakistan. ${ }^{27}$ There are lots of memories from the Partition days. There are lots of memories of friends left behind. Lots of stories in the family of people who have gone through similar things that Khamosh Paani talks about...it deals with women and how few choices they have in life, how all their choices are related to the men in their lives whether they are their fathers, or brothers, or their husbands, and ultimately their sons, they are answerable to all of them...they seem to be the keepers of their morals and their values. Very few women really have a choice in rural India or Pakistan...I think to be a part of that voice that comes from the sub-continent was very important to me. (Comments in prelude to Silent Waters) 
As these reflections indicate, the filmmaker and her lead actor step into a shared history and culture, the very same one from which Veero/Ayesha steps out to tell her story. All are positioned in a filmic time traversing past and present, a time which presents - with due complexity — the various historical, cultural, and personal junctures at which shared experiences reverberate. To borrow Alisa Lebow's phrasing (2012), the "II' inheres in the 'we'," and vice versa (33). In bringing forth a multi-layered biographical story, and making it accessible for wider audiences, Sumar's filmic historiographical intervention into regional history provides Veero/Ayesha the opportunity to step out of her pre-determined subject position in order to attest to the irreducibly complex gendered implications of Partition, Islamization and contemporary religious nationalism.

As Veero remains her own sole witness to the emotional and physical toll of becoming Ayesha, and to her new identity's subsequent personal history, the specific opportunities afforded by auto/biography are brought into sharp relief. Whereas recording history is silent story-telling amassing collected facts (however they may be ordered or presented by the historian), auto/biography breaks the silence, finding a personal voice for the telling of individual histories with experiential facts (however subjective, non-linear, or fictionalized such presentations may be). This is particularly true of auto/biographical film, where the filmic storyteller or protagonist 
also takes on an inescapably visual identity, that is inevitably historical, cultural, racial, or gendered. This necessity, in turn, brings into the fold yet another aspect of auto/biographicalhistoriography: its mutually constitutive relationship to the historical placement and selfidentification of viewers, who may have lived through or otherwise experienced the same periods and contexts depicted on screen. As Rosenstone (2013) points out in a remark cited at the very beginning of the present essay: "Film does more than want to teach the lesson that history hurts; it wants you, the viewer, to experience the hurt (and pleasures) of the past" (18). From the filmmaker (its storyteller), through the film's subjects (its story; its characters), all the way to the viewer (potentially an informed participant of the historical and auto/biographical events), the film experience, as a differentiating totality, bridges manifold contextual historical experiences through the auto/biographical interventions of each element. As a film reconstructs and revisions history through auto/biographical stories, it simultaneously articulates and archives a multi-layered historiographical take on the past through multiple personal lenses.

Commenting on the conspicuous absence of women's accounts of the Partition, Geetanjali Singh Chanda (2014) pithily notes: “The mainstream dominant narrative silenced women's voices and displaced them as subjects of even their own stories" (193). In view of this absence, women's auto/biographical narratives, culturally and academically marginal as they may be, make for a valuable contribution to revisionist historiographical cinema in the present. As 
opposed to written histories, the mechanics of cinema afford such accounts an active space for contesting the past. Cinema can give faces to events and encounters, testify to emotional and interpersonal complexities, and offer expression to visual, dialogic, and tonal differences, contributing in so many ways to an aesthetic experience that is constitutively open to new interpretations, revised perceptions, critical evaluations, and pedagogical appropriations as a practice of revisionist history. In the process, as illustrated by Silent Waters, cinema can locate the filmmaker tacitly within the filmic narrative as an auto/bio-historiographer.

\section{Conclusion}

An increasing number of Muslim women and feminist practitioners, from within the Muslim world and beyond, have turned to film as their medium of choice for registering resistance and creating awareness around women's oppression in Muslim-majority societies such as Iran,

Pakistan, Saudi Arabia and Turkey (Rastegar, 2013: 87). In light of this welcome surge in activity, it is more important than ever to draw attention to the struggle of Muslim women filmmakers who, like Sumar, have asserted their right to retrieve, portray, and thereby archive, historical accounts of women's experiences that may otherwise be lost to time. This task is all the more urgent given "the ideological dysfunctions and structural limitations" that routinely 
hinder creative expressions by independent filmmakers working on crucial and sensitive topics

(Ahmad, 2014: 153). Works by Muslim women filmmakers entail the specificities of their

personal stories, forms of activism and modes of production; they also index wide-ranging socio-

political, cultural, and religious constraints, censorship policies, and challenges accompanying

the circulation and exhibition of work, both within Muslim-majority countries and

internationally.

At the same time, however, despite these structural commonalities, the historiographical

self-positioning of Muslim women filmmakers—whether participatory or tacit—also requires

forms of close contextual insight, specific to individuals and their experiential involvement in the

histories they are telling or retelling. It is at this critical juncture that auto/biographical-

historiography attains its critical currency, or at least ought to, as I have argued in this essay. A

critical examination of the extraordinarily wide variety of auto/biographical cinemas produced

by Muslim women filmmakers — currently overlooked in Cinema Studies—can reveal a plethora

of unique historiographical insights, attentive to the multiple ways filmmakers are embedded in

specific regions, religions, cultures and political landscapes - and in films themselves. As in the

case of Sumar's Silent Waters, the positioning of the filmmaker as an auto/bio-historiographer

makes possible new perspectives on the rapidly growing field of auto/biographical and first-

person expression in film, and of auto/biographical studies more broadly. 


\section{REFERENCES:}

Ahmad, Ali Nobil. (2014). "Independent Filmmaking in Pakistan: An Interview with Sabiha Sumar." In Bioscope, vol. 5, no. 2. 153-162.

Ahmed, Ishtiaq. (2002). "The 1947 Partition of India: A Paradigm for Pathological Politics in India and Pakistan.” In Asian Ethnicity, vol. 3, no. 1. 9-28.

Alavi, Hamza. (1988). "Pakistan and Islam: Ethnicity and Ideology." State and Ideology in the Middle East and Pakistan. Edited by Fred Halliday and Hamza Alavi. New York: Palgrave Macmillan Press. 64-111.

Amnesty International. (1999). "Pakistan: Honour-killings of Girls and Women."

http://web.amnesty.org/library/Index/engASA330181999. Accessed 25 March 2020.

Bhabha, Homi. K. (1967). “Foreword.” Frantz Fanon. Black Skins, White Masks, translated by Charles Lam Markmann. New York: Grove Press. vii-xxvi.

Butalia, Urvashi. (1988). The Other Side of Silence: Voices from the Partition of India. New Delhi: Penguin Books.

Chanda, Geetanjali Singh. (2014). "Recognition and Rejection of Sikh Identity in Film.” In Sikh Formations, vol. 10, no. 2. 187-202.

Citizens Archive of Pakistan (Oral) History Project. http://www.citizensarchive.org/projects. Accessed 8 July 2020.

Dey, Arunima. (2017). "Violence Against Women During the Partition of India: Interpreting Women and their Bodies in the Context of Ethnic Genocide." In ES Review. Spanish Journal of English Studies. no. 37, May. 103-18.

Didur, Jill.(2006). Unsettling Partition: Literature, Gender, Memory. Toronto: University of Toronto Press. 
Everett, Wendy.(2007). "Through the I of the Camera: Women and Autobiography in Contemporary European Film." In Studies in European Cinema. vol. 4, no. 2. 125-136.

Ferro, Marc. (1987). “Does A Filmic Writing of History Exist?” In Film \& History. vol. 17, no. 4. 81-89.

Ferro, Marc. (1983). "Film as an Agent, Product and Source of History.” In Journal of Contemporary History. vol. 18, no. 3. 357-364.

First Run Features. "Silent Waters Press Kit." http://www.firstrunfeatures.com/presskits/silent waters press kit/silent waters press kit.pdf. Accessed 5 July 2020.

First Run Features. "The Human Rights Watch DVD Collection." http://firstrunfeatures.com/hrwboxset.html. Accessed 30 September 2020.

Fuchs, Maria-Magdalena, Simon Wolfgang Fuchs. (2020). "Religious Minorities in Pakistan: Identities, Citizenship and Social Belonging." In South Asia: Journal of South Asian Studies, vol. 43 , no. 21. 52-56.

Gani, Martin. (2009). “Sabiha Sumar-Pakistan's Award-Winning Filmmaker.” Middle East Institute, 2 December 2009. https://mei.edu/publications/sabiha-sumar-pakistans-award-winningfilmmaker. Accessed 5 June 2020.

Grove A. K. (2007). Political Leadership in Foreign Policy. New York: Palgrave Macmillan Press.

Guha, Ramchandra. (2007). India After Gandhi: The History of the World's Largest Democracy. New Delhi: Picador.

Guzder, Jaswant. (2011). "Women who jump into wells: Reflections on suicidality in women from conflict regions of the Indian subcontinent." In Transcultural Psychiatry. vol. 48, no. 5. 585-603.

Hajari, Nisid. (2015). Midnight Furies: The Deadly Legacy of India's Partition. New York: Houghton Mifflin Harcourt. 
Hariharan, Githa. (2020). “Blood Thirsty Honour.” The Telegraph, 11 October 2004. http://www.countercurrents.org/gender-hariharan111004.htm. Accessed 10 June 2020.

Hartsock, Nancy C. M. (1998). The Feminist Standpoint Revisited and Other Essays. Boulder: Westview Press.

Hirsch, Joshua. (2008). "Post-traumatic Cinema and the Holocaust Documentary." Trauma and Cinema: Cross-Cultural Explorations. Edited by E. Ann Kaplan and Ban Wang. Hong Kong: Hong Kong University Press. 93-121.

Hunt, Nigel C. (2010). Memory, War and Trauma. New York: Cambridge University Press. Hussain, Zahid. (2007). Frontline Pakistan: The Struggle with Militant Islam. New York: Columbia University Press. 2007.

Imran, Rahat. (2016). Activist Documentary Film in Pakistan: The Emergence of a Cinema of Accountability. New York: Routledge.

Imran, Rahat. (2008). "Deconstructing Islamization in Pakistan: Sabiha Sumar Wages Feminist Cinematic Jihad through a Documentary Lens.” In Journal of International Women's Studies, vol. 9 , no. 3. 117-154.

Imran, Rahat. (2005). "Legal Injustices: The Zina Hudood Ordinance of Pakistan and its Implications for Women.” In Journal of International Women's Studies, vol. 7, no. 2. 78-100.

Isphahani, Farahnaz. (2017) Purifying the Land of the Pure: A History of Pakistan's Religious Minorities. Oxford: Oxford University Press.

Jalal, Ayesha. (1991). "The Convenience of Subservience: Women and the State of Pakistan." Women, Islam and the State. Edited by Deniz Kandiyoti. London: Palgrave Macmillan Press. 77114.

Khan, Yasmin. (2017). The Great Partition: The Making of India and Pakistan. New Haven: Yale University Press. 
Kleinhans, Chuck. (1984). "Forms, Politics, Makers and Contexts: Basic Issues for a Theory of Radical Political Documentary." "Show Us Life": Toward a History and Aesthetics of the Committed Documentary. Edited by Thomas Waugh. New Jersey: Scarecrow Press. 318-342.

Kolkata Partition Museum. https://kolkata-partition-museum.org/. Accessed 9 July 2020.

Langer, Lawrence L. (1991). Holocaust Testimonies: The Ruins of Memory. New Haven: Yale University Press.

Lebow, Alisa. (ed). (2012). "Introduction." The Cinema of Me: The Self and Subjectivity in First Person Documentary. London: Wallflower Press. 28-56.

Menon, Ritu and Bhasin, Kamla. (1997). “An Exchange of Women: Abduction, Forcible Recovery, Silence: The Tragic Irony of Partition's Unsung.” In Outlook, 28 May. https://www.outlookindia.com/magazine/story/an-exchange-of-women/203611. Accessed 9 July 2020.

Mernissi, Fatima. (2003). “The Meaning of Spatial Boundaries.” Feminist Postcolonial Theory: A Reader. Edited by Lewis, Reina and Mills, Sara. New York: Routledge. 489-501.

Minh-ha. Trinh T. (1991). When the Moon Waxes Red: Representation, Gender and Cultural Politics. New York: Routledge.

Morrison, Toni. (1995). "The Site of Memory." Inventing the Truth: The Art and Craft of Memoir. Edited by William Zinsser. New York: Houghton Mifflin. 83-105.

Mumtaz, Khawar and Shaheed, Farida. (1987). Women of Pakistan: Two Steps Forward, One Step Back? Lahore: Vanguard Books.

Noorani, A. G. (2002). Islam and Jihad: Prejudice versus Reality. London: Zed Books.

Nora, Pierre. (1989). "Memory and History: Les Lieux de Memoire.” In Representations, vol. 26. 7-24. 
Oishi, Eve. (2006). "Screen Memories: Fakeness in Asian American Media Practice." $F$ is for Phony: Fake Documentary and Truth's Undoing. Edited by Juhasz, Alexandra and Lerner, Jesse. Minneapolis: University of Minnesota Press. 196-219.

Partition Museum Amritsar. http://www.partitionmuseum.org/museum/. Accessed 9 July 2020.

Preserving Memories of Partition of India. https://partitionofunitedindia.weebly.com. Accessed 9 July 2020.

Ramzi, Shanaz. (2003). “Interview: Sabiha Sumar.” In Newsline. October. http://newslinemagazine.com/magazine/interview-sabiha-sumar-2/. Accessed 1 October 2020.

Rastegar, Kamran. (2013). "Film Studies.” Encyclopedia of Women and Islamic Culture:

Disciplinary Paradigms and Approaches: 2003-2013. Edited by Joseph, Suad. Brill Online. 87102.

Renov, Michael. (1993). "Towards a Poetics of Documentary.” Theorizing Documentary. Edited by Renov, Michael. New York: Routledge. 12-36.

Rosenstone, Robert A. (2013). History on Film/Film on History. New York: Routledge.

Rosenstone, Robert A. (1995). Visions of the Past: The Challenge of Film to Our Idea of History. Cambridge: Harvard University Press.

Sadasivam, Bharati. (2004). 'Partitioned Lives.’ In Frontline Magazine. June 18. vol. 21, no. 12.

Saksena, N. S. (1990). Communal Riots in India. Noida: Trishul Publishers.

Shaikh, Nermeen. (2005). “Interview with Sabiha Sumar.” In Asia Society. April 8. https://asiasociety.org/interview-sabiha-sumar. Accessed 12 July 2020.

Singh, Gurdit and C. Fair, Carol. (1999). "The Partition of Punjab: Its Impact Upon Sikh Sacred and Cultural Space." Region and Partition: Bengal, Punjab and the Partition of the 
Subcontinent. Edited by Talbot, Ian and Singh, Gurharpal. Oxford: Oxford University Press. 253-268.

Stanley, Liz. 1993). “On Auto/Biography in Sociology.” In Sociology, vol. 27, no. 1. 41-52.

Sumar, Sabiha. Silent Waters. (2003) (Urdu title: Khamosh Paani). First Run Features.

Sundar, Pavitra. (2010). "Silence and the Uncanny: Partition in the Soundtrack of Khamosh Pani." In South Asian Popular Culture, vol. 8, no. 3. 277-290.

Talbot, Ian. (2000). Inventing the Nation: India and Pakistan._New York: Oxford University Press.

The 1947 Partition Archive. https://www.1947partitionarchive.org/mission. Accessed 9 July 2020.

Vidhi Films. (2020). "Reaching out to a global audience and market." https://www.vidhifilms.com/about/global-audience-and-market. Accessed 4 June 2020.

ENDNOTES:

Acknowledgement: This paper is written during the author's Post-doctoral Research Fellowship project at the Department of Film and Screen Media, University College Cork, Ireland. This project has received funding from the European Union's Horizon 2020 research and innovation programme under the Marie Sklodowska-Curie grant agreement No 837154.

The author thanks Professor Laura Rascaroli for her feedback during the writing of this paper.

${ }^{1}$ Rosenstone, Robert. A. History on Film/Film on History. Routledge, USA, 2013. (pg-18). 
${ }^{2}$ Founder of Pakistan Muhammad Ali Jinnah's first Presidential Address to the Constituent Assembly of Pakistan on August 11, 1947. Jalal, Ayesha. The Struggle for Pakistan: A Muslim Homeland and Global Politics. The Belknap Press of Harvard University Press, USA. 2014. (pg-53).

${ }^{3}$ General Zia-ul-Haq's statement in an interview given to the British Broadcasting Corporation (BBC) on April 15, 1978. Chamieh, Jebran. ‘Contemporary Fundamentalist Regimes and Movements.' Traditionalists, Militants and Liberals in Present Islam. Research and Publishing House, Montreal, Canada. 1995. (pg-170).

${ }^{5}$ Sharia laws are Islamic socio-religious laws, based upon the literal interpretation of the Quran, dating back more than 1400 years, and believed by Muslims to be the divine word of God, and the Sunnah (the Islamic Traditions based on Prophet Mohammad's life). (Imran, 2016: 11).

${ }^{6}$ In an interview with Nermeen Shaikh, Sumar elaborated that Silent Waters was initially planned as a documentary film; doing research in Pakistan and India on the topic of abducted women during Partition she opted for the narrative format: "I didn't want to do this as a documentary at all because it would mean scratching people's wounds. These women had been through the most awful violence one can imagine and a lot of women were now languishing in ashrams in India because their families had refused to accept them."

${ }^{7}$ Although scholars, such as Alka Kurian (2012), Pavitra Sundar (2010), Humaira Saeed (2009), Shazia Rahman (2011), Shahnaz Khan (2009), among others, have discussed Silent Waters from various historical, political, and gender-specific angles, none have thus far engaged with the film from an auto/biographical-historiographical angle.

${ }^{8}$ Given constraints of space, and the enormity of the topic of Partition, it is not within the scope of this paper to offer comparative studies with other films (whether Pakistani or Indian) on the topic of the Partition.

${ }^{10}$ For detailed discussion, see Isphahani (2017: 11).

${ }^{11}$ For detailed discussion on historical and cultural notions of 'honour' see Stewart, Frank Henderson. (1994). Honor. Chicago: University of Chicago Press.

12 Ishtiaq Ahmed elaborates on his use of the term: "The expression 'pathological politics' is used here to indicate that individuals not only prefer people of their own ethnic stock, culture, religion, language, nationality and so on, but dislike and despise those belonging to other groups...the roots of pathological politics in the intrastate and interstate politics of India and Pakistan are to be traced to the bloody division of the British Indian empire in 1947" (2002: 10-11).

${ }^{13}$ Notable films on Partition include: 1947/Earth. Dir. Deepa Mehta. India.1998; Gadar: Ek Prem Katha. Dir. Anil Sharma. Zee Telefilms,. India. 2001; Garam Hawa. Dir. M.S. Sathyu. Unit 3 mm. India. 1973; Hey Ram! Dir. Kamal Hassan. Raajkamal Films International. India. 2000; Silent Waters. Dir. Sabiha Sumar. Vidhi Films. Pakistan. 2003; Mammo. Dir. Shyam Benegal. National Film Development Corporation. India. 1994; Pinjar. Dir. Chandra Prakash Dwivedi. Lucky Star Entertainment. India. 2003. 
${ }^{14}$ English translations of all dialogue is given as it appears in the film's subtitles.

${ }^{15}$ Nizam-e-Mustafa is a broad reference to the way of life based on the teachings of Prophet Muhammad. The Zia regime manipulated and politicized the term to serve its vested interests (Jalal, 1991: 101).

${ }^{16}$ Zulfikar Ali Bhutto was hanged by General Zia-ul-Haq's regime on 4 April 1979.

${ }^{17} \mathrm{Jihad}$ is a moral, spiritual, political, or physical struggle sanctioned by Islam when faced with a threat to one's life, faith, or rights. However, the concept of jihad as a holy war was politicized by the Zia regime to promote its Islamization process. (see Noorani, 2002: 43-57).

${ }^{18}$ Dr. Israr Ahmed, a notoriously orthodox and gender-biased member of the Religious Council formed under the Zia regime, introduced the concept of chador aur chardiwari to marginalize women's participation in public life (Mumtaz and Shaheed, 1987: 83).

${ }^{19}$ For further discussion on the issue of women and "honour", see Hariharan (2004).

${ }^{20}$ Among other horrific and violent means, committing suicide by jumping into a well is a common means of death for raped women even today, particularly in the Punjab where the act of “drowning” oneself also carries metaphoric significance in terms of retaining one's honour. See Amnesty International's report on the subject.

${ }^{21}$ An organized women's movement began to emerge in opposition to Zia's Islamization process in the late 1970s in Pakistan, registering resistance through public rallies, street theatre, literature, and the formation of the Women's Action Forum (WAF), an umbrella organization with rapidly growing popularity and presence in all the major cities of the country (Mumtaz and Shaheed, 1987: 71).

The sepia-tone is a chemically achieved colouration that changes black-and-white prints to shades of reddish-brown. This technique is used to add an archival and antique quality to photographs and film. As a cinematic strategy, sepia-toned images and footage are usually inserted in films to convey images of historical events, and past traumatic experiences through flashbacks. For further discussion of representation of time through the film medium, see Cardwell, Sarah. (2003). “About Time: Theorizing Adaptation Temporality, and Tense.” In Literature/Film Quarterly. Vol. 31, No. 2. 82-92.

${ }^{23}$ The Gutka is a collection of hymns from the Guru Granth Sahib, the Sikh Holy Book, which is used in private worship.

${ }^{24}$ For a discussion of Who Will Cast the First Stone? see Imran, 2016: 45.

${ }^{25}$ In his discussion of the Holocaust, Lawrence Langer (1991) identifies and differentiates on the functions of "deep" and "common" memory: "Deep memory tries to recall the Auschwitz self as it was then; common memory has a dual function: it restores the self to its normal pre- and postcamp routines but also offers detached portraits, from the vantage point of today, of what it must have been like then" (22).

${ }^{26}$ In Pakistan's hostile environment of authoritarian regimes, religious fundamentalism, and rigid censorship policies, Pakistani independent filmmakers have had to largely rely on funding from Western donor agencies, NGOs, and media collaborations to produce and exhibit films that portray and critique sensitive religio-political, and gender issues. These have included Western film festivals, and TV channels such as HBO, ZDF/Arte, Channel 4, Discovery Times Channel, CBC, CNN, and PBS. (Imran, 2016: 190).

${ }^{27}$ In 1977, the government of Pakistan renamed Lyallpur (a British colonial name) as Faisalabad (City of Faisal) to honour the state visit of the thenmonarch of Saudi Arabia, King Faisal bin Abdul Aziz. 